\title{
Physiological and anatomical responses of Eucalyptus camaldulensis leaves to glyphosate application
}

\author{
Diego Meloni $\mathbb{(}^{1 *}$ Carlos Arberto Martínez $\mathbb{0}^{2}$ María Gabriela Targa $\oplus^{1}$ Alicia Fraño $\oplus^{1}$ Alejandra \\ Catán ${ }^{1}$
}

${ }^{1}$ Universidad Nacional de Santiago del Estero, Belgrano Sur Avenue, 1912, Post Code G4200, Santiago del Estero, Argentina
${ }^{2}$ University of São Paulo, Bandeirantes Avenue, 3900, Monte Alegre, Post Code 14040-901, Ribeirão Preto, São Paulo, Brazil

Original Article

*Corresponding author: diealt2020@gmail.com

Keywords:

Ecophysiology

Pesticides

Plant anatomy

Palavras-chave:

Ecofisiologia

Agrotóxicos

Anatomia vegetal

Received in

2021/05/28

Accepted on

2021/09/21

Published in 2021/10/11

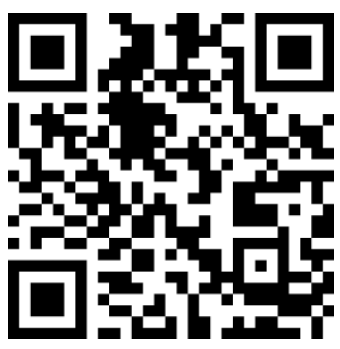

\section{(cc) BY}

DOI:

https://doi.org/10.34062/afs. v8i3.12483
ABSTRACT: The use of herbicides is a usual practice in E. camaldulensis nurseries and plantations. The most widely used herbicide is glyphosate, whose drift damages this plant leaves. Although the mechanism of action of glyphosate is well known, it is not clear which alterations lead to the death of plants. The aim of this work was to assess the physiological and anatomical responses of leaves of $E$. camaldulensis seedlings to glyphosate application. Tests were performed on oneyear-old seedlings sprayed with 0,65 and $130 \mathrm{~g}$ a.e. ha ${ }^{-1}$ glyphosate. Ten days after the application, we measured gas exchange and fluorescence emission of chlorophyll a. We also quantify the concentrations of chlorophyll a, shikimate, carbohydrates, $\mathrm{K}^{+}$and $\mathrm{Mg}^{2+}$, and the anatomical parameters of epidermis and mesophyll. Data was contrasted using Fisher's test $(p<0.05)$. We concluded that glyphosate alters the physiology of E. camaldulensis, inhibiting photosynthesis, changing the metabolism of carbohydrates and the ionic homeostasis. Tissue disorganization, heavily marked at the level of mesophyll, indicates definite alterations.

\section{Respostas fisiológicas e anatômicas de folhas de Eucalyptus camaldulensis à aplicação de glifosato}

RESUMO: O uso de herbicidas é uma prática usual em viveiros e plantações de E. camaldulensis. O herbicida mais utilizado é o glifosato cuja deriva danifica as folhas destas plantas. Embora o mecanismo de ação do glifosato seja bem conhecido, não está claro quais alterações levam à morte das plantas. O bjetivo deste trabalho foi avaliar as respostas fisiológicas e anatômicas de folhas de mudas de E. camaldulensis à aplicação de glifosato. Os experimentos foram realizados em mudas de um ano de idade pulverizadas com 0,65 e $130 \mathrm{~g}$ e.a. ha ${ }^{-1}$ de glifosato. Dez dias após a aplicação, foram medidas as trocas gasosas e a emissão de fluorescência da clorofila a. Também foram quantificadas as concentrações de clorofila a, chiquimato, carboidratos, $\mathrm{K}^{+}$e $\mathrm{Mg}^{2+}$, e os parâmetros anatômicos da epiderme e do mesofilo. Os dados foram contrastados usando o teste de Fisher ( $\mathrm{p}<0,05$ ). Em conclusão o glifosato altera a fisiologia de E. camaldulensis, inibindo a fotossíntese, mudando o metabolismo dos carboidratos e a homeostase iônica. A desorganização do tecido, fortemente marcada ao nível do mesofilo, indica alterações definidas. 


\section{Introduction}

Weed management is one of the most relevant forestry practices in eucalyptus nurseries and plantations. It is performed with mechanical or chemical methods, or the combination of both (Cerveira Junior et al. 2020).

The recurrent use of herbicides in forest plantation management can be harmful for the crop itself (De Carvalho et al. 2018). Some studies have demonstrated that the contact of herbicides with the leaves of forest species might cause considerable losses in timber production because of growth decline and plant death (Minogue and Osiecka 2015; Santos et al. 2015). The magnitude of the damage is proportional to the dose recommended for weed control (Batista et al. 2018).

Glyphosate (N-phosphonomethyl glycine) is among the most widely used herbicides (Gomes et al. 2019) because it controls a broad spectrum of weeds. It is systemic, nonresidual, and nonselective. It is easily transported from the leaves to the meristematic tissues and acts inhibiting the 5enolpyruvyl-shikimate-3-phosphate synthase (EPSPS), responsible for the synthesis of chorismate, an intermediary in the shikimic acid pathway leading to the synthesis of aromatic amino acids (Cruz et al. 2021).

Although the mode of action of glyphosate is well known, the metabolic and anatomical changes consistent with plant death after treatment with the herbicide are not clear. Herbicides might decrease the photosynthetic rate (Khan et al. 2020) and alter the metabolism of carbohydrates (Orcaray et al. 2012). The analysis of chlorophyll a fluorescence constitutes a sensitive and nondestructive method for the assessment of the changes produced in the photochemical stage of photosynthesis. It has been recently used to evaluate the degree of damage of the photosynthetic apparatus under different conditions of environmental stress such as extreme temperatures (Van der Westhuizen et al. 2020), drought (Badr and Brüggemann 2020), salinity (Meloni et al. 2017), and herbicides (Souza et al. 2014).

Glyphosate might alter the mineral composition of plants, although the reported results are contradictory (Gomes et al. 2014). In vegetable tissues, the phosphonate and carboxyl groups of the glyphosate molecule can link to divalent cations, immobilizing them (Zobiole et al. 2011). There are no studies on the effect of herbicides on the mineral composition of eucalyptus.

The impact of the application of herbicides may be observed in the internal anatomy and the epidermis of leaves. However, there are only a few studies on the description of the microscopic damage in leaves (Freitas-Silva et al. 2020). The use of physiological and anatomical variables constitutes a tool to assess the damage of herbicides on woody species (Lima et al. 2017).
The aim of this work is to evaluate the physiological and anatomical responses to glyphosate application on leaves of $E$. camaldulensis seedlings.

\section{Material and Methods \\ Vegetal material}

Essays were performed on one-year-old Eucalyptus camaldulensis seedlings grown in plastic pots containing loam soil fertilized with $\mathrm{N}$ P-K (20:5:20). The pots were placed in a greenhouse and received daily manual irrigation to ensure adequate water availability.

Plants were sprayed with Roundup® Full II (Monsanto Argentina), containing 65\% (w/w) glyphosate potassium salt (N-phosphonomethyl glycine) as active element at concentrations of either 0,65 or $130 \mathrm{~g}$ a.e. $\mathrm{ha}^{-1}$. Ten days after the herbicide application, measurements of both fluorescence emission and gas exchange were performed, and samples were collected to conduct chemical determinations.

During the light and dark periods, the average values of air temperature were $25^{\circ} \mathrm{C}$ and $15^{\circ} \mathrm{C}$, respectively. The daily average value of solar irradiance was $1,500 \mu \mathrm{mol} \mathrm{m} \mathrm{m}^{-2} \mathrm{~s}^{-1}$.

\section{Photosynthesis and chlorophyll a concentration \\ Gas exchange measurements were} performed at 8:00 a.m. on the first three fullydeveloped leaves from the apex. An infrared gas analyzer (IRGA-LCpro ${ }^{+}$System ADC, BioScientific Ltd.) was used in a closed system at a $\mathrm{CO}_{2}$ concentration of $380 \mathrm{ppm}$ and $26^{\circ} \mathrm{C}$. An artificial light source was applied, with a light intensity of approximately $1500 \mu \mathrm{mol} \mathrm{m} \mathrm{m}^{-2} \mathrm{~s}^{-1}$ (Portela et al. 2019). Carbon photosynthetic assimilation $(A)$, stomatal conductance $\left(\mathrm{g}_{\mathrm{s}}\right)$, intercellular $\mathrm{CO}_{2}$ concentration $\left(\mathrm{C}_{\mathrm{i}}\right)$, and carboxylation efficiency $\left(A / C_{\mathrm{i}}\right)$ were determined.

Chlorophyll a concentration was quantified on the fourth fully-developed leaf from the apex. Leaf samples $(0.2 \mathrm{~g})$ were ground in a mortar with $80 \%$ acetone $(\mathrm{v} / \mathrm{v})$; the extract was filtered through glass wool and centrifuged at 15,000 x $\mathrm{g}$ for five minutes. The supernatant was collected, and the absorbances were measured at 663, 647, and 470 $\mathrm{nm}$. The concentration of chlorophyll a was calculated according to the Lichtenthaler and Welburn equations (1983).

\section{Chorophyll a fluorescence}

Chorophyll $a$ fluorescence emission kinetics was measured on the same leaves used for the photosynthesis measurements with a Handy PEA portable fluorimeter (Plant Efficiency Analyzer, Hansatech Instruments Ltd, King's Lynn Norfolk, UK). Measurements were performed at 8:00 a.m., 
after the acclimatization of the leaves in darkness for 30 minutes. Fluorescence emission on leaves was induced by red light $(650 \mathrm{~nm})$, with an intensity of $3,000 \mu \mathrm{mol}$ photons $\mathrm{m}^{-2} \mathrm{~s}^{-1}$ from a matrix containing three diodes focused on a $4 \mathrm{~mm}$ diameter point and registered for one second. The OJIP fluorescence transients obtained for each treatment were analyzed according to JIP test, and the index of total performance $\left(\mathrm{PI}_{\text {Total }}\right)$ was calculated according to Gama et al. (2013) using the Biolizer software (Bioenergetics Laboratory, University of Geneva, Switzerland).

Concentrations of shikimate, carbohydrates, and ions

Shikimate was extracted and quantified according to the Singh and Shaner technique (1998). One hundred milligrams of leaves were homogenized in $30 \mathrm{ml} \mathrm{HCl} 0.25 \mathrm{~N}$. The extract was centrifuged at $25,000 \mathrm{~g}$ for $15 \mathrm{~m}$. A $40 \mu \mathrm{l}$ aliquot of the supernatant was collected to add $0.5 \mathrm{ml}$ of periodic acid $1 \%$. After $3 \mathrm{~h}, 0.5 \mathrm{ml} \mathrm{NaOH} 1 \mathrm{~N}$ and $0.3 \mathrm{ml}$ glycine $0.1 \%$ were incorporated. The solution was vigorously mixed, and the absorbance was measured at $380 \mathrm{~nm}$ in a spectrophotometer.

Soluble carbohydrates and starch were quantified following the method described by Portela et al. (2019).

For the analysis of ions, leaves were dried in a forced ventilation oven at $70^{\circ} \mathrm{C}$ for $48 \mathrm{~h}$. Then, they were ground in Wiley-type mill grinder, and the material was digested in a mixture of $\mathrm{HNO}_{3} / \mathrm{HClO}_{4}$. The resulting solutions were diluted in deionized water to determine $\mathrm{K}^{+}$concentration with a flame photometer (Corning, Model 400, USA) and $\mathrm{Mg}^{2+}$ concentration by atomic absorption spectrometry (GBC, Model 908 AA, USA), following the protocol described by Al-Kahayri (2002)

\section{Anatomy of leaves}

Mature and fully developed leaves located from the fourth node to the apex were collected to make a homogeneous set for each treatment and a control sample; they were preserved in Carnoy's solution until the moment of processing the material. Blades were extracted from the set of leaves to perform observations and quantifications of the epidermis and anatomy. For the extraction of epidermis, we performed mesophyll digestion with $50 \%$ sodium hypochlorite, a repeated washing with distilled water, an immersion in $5 \%$ chloral hydrate for $5 \mathrm{~m}$, and the mounting on slides using gelatinglycerin glue. To obtain the transverse sections of the leaves, mesophyll was dehydrated with ethyl series and embedded in paraffin. Cross-sections with $10 \mu \mathrm{m}$ thick, obtained using a rotary microtome, were stained with safranin - fast green, and mounted in Canada balsam (Dizeo, 2000). Microscopic observations were performed using a stereo-microscope and anatomical attributes were measured using a Motic BA 210 image processor. In lower epidermis we observed stomatal density, and in the transverse section of leaves, we determined the palisade parenchyma, spongy parenchyma, and total mesophyll thickness.

\section{Statistical analysis and experimental design}

An experimental design completely at random with ten repetitions was used, and the results were analyzed with ANOVA and Fisher's test (Fisher $\mathrm{p}<0.05)$.

\section{Results and discussion}

Glyphosate produced a sharp reduction in the photosynthetic rate (Figure 1A). The $65 \mathrm{~g}$ a.e. $\mathrm{ha}^{-1}$ and $130 \mathrm{~g}$ a.e. $\mathrm{ha}^{-1}$ doses decreased in $33 \%$ and $71 \%$ the net photosynthesis when compared with the control, respectively. Stomatal conductance had a similar behavior (Figure 1B), with reductions of 33 y $67 \%$ in both doses with respect to the control, respectively. The inhibition of $\mathrm{CO}_{2}$ assimilation after applying glyphosate has been observed in other species, but the inhibition mechanism remains unknown (Gomes et al. 2014). The decrease in the net photosynthesis was partly caused by the stomatal closure because both gas exchange variables had the same response to the glyphosate application. However, in the $65 \mathrm{~g} \mathrm{ha}^{-1}$ glyphosate dose the intercellular $\mathrm{CO}_{2}$ concentration did not vary with respect to the control (Figure 1C), indicating that $\mathrm{CO}_{2}$ did not limit photosynthesis in that dose. In agreement with that result, both doses of the herbicide produced a decrease in carboxylation efficiency (Figure 1D), and thus a nonstomatal inhibition of photosynthesis. Glyphosate may decrease carboxylation efficiency by decreasing the levels of ribulose-1,5biphosphate, and 3-phosphoglyceric acid (Siehl 1997). In Lupinus albus, glyphosate produced inhibition of $26 \%$ in the Rubisco activity (De María et al. 2006).

Both doses of glyphosate reduced the chlorophyll a concentration (Figure 1E). This response was observed in other species and was associated to pigment degradation or synthesis inhibition (Huang et al. 2012). The accumulation of reactive oxygen species might be responsible for the degradation of photosynthetic pigments (Radwan and Fayez 2016). Synthesis inhibition in chlorophyll a might be caused by low glycine and glutamate concentrations, necessary for the synthesis of $\delta$-aminolevulinic acid, a precursor of this photosynthetic pigment (Serra et al. 2013). 


\section{Meloni et al.}
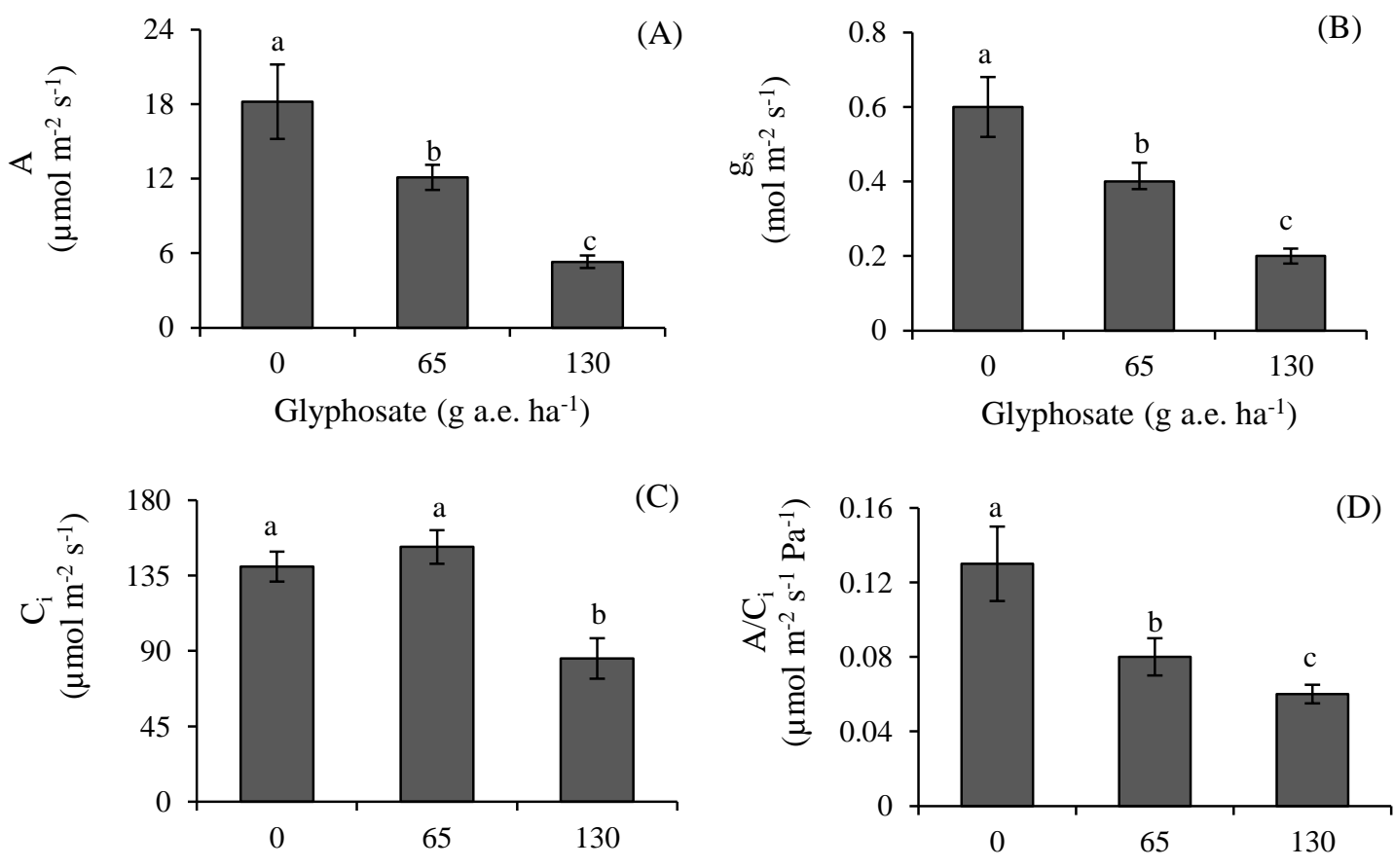

Glyphosate (g a.e. ha-1)

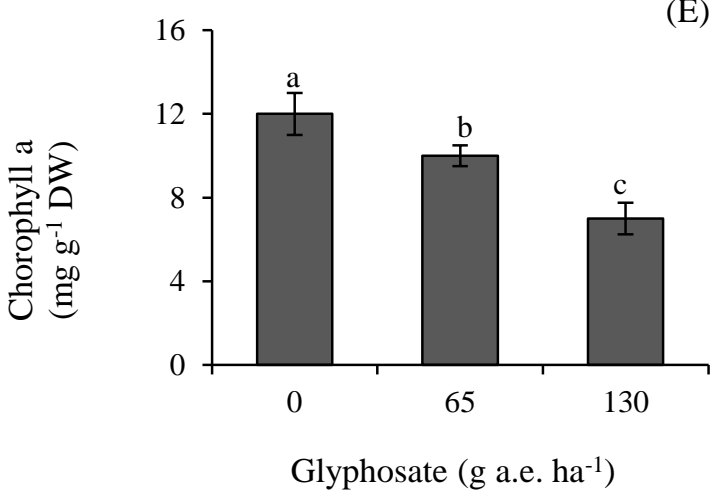

(E)

Glyphosate (g a.e. ha-1)

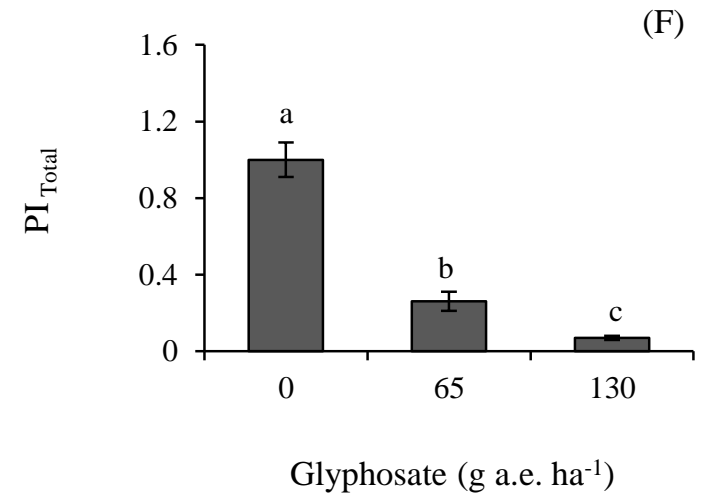

Figure 1. Carbon photosynthetic assimilation (A), stomatal conductance (B), intercellular $\mathrm{CO}_{2}$ concentration (C), carboxylation efficiency (D), chlorophyll a concentration (E) and index of total performance (F) in $E$. camaldulensis plants submitted to 0,65 and $130 \mathrm{~g}$ a.e $\mathrm{ha}^{-1}$ glyphosate. Vertical bars represent the mean standard deviation. Different letters denote significant differences at level $\mathrm{P}<0.05$ according to Fisher's test.

As a consequence of the impact of the herbicide on the photosynthetic electron transport chain, an important decrease in the total performance index ( $\left.\mathrm{PI}_{\text {Total }}\right)$ was observed (Figure $1 \mathrm{~F}) . \mathrm{PI}_{\text {Total }}$ is a fluorescence parameter highly sensitive to environmental stresses that indicates the vitality of the photosynthetic apparatus (Amin et al. 2016). Both doses of glyphosate produced an important decrease in $\mathrm{PI}_{\text {Total }}$, which indicates an inhibition in the photochemical stage of photosynthesis. This result was partly caused by the decrease in the content of Chlorophyll a. Gomes et al. (2017) also reported an inhibition in the photochemical stage of photosynthesis in Salix miyabeana sprayed with glyphosate because of a decrease in the concentration of photosynthetic pigments and plastoquinone. In Glycine max, glyphosate inhibited the photochemical stage of photosynthesis by decreasing the abundance of the $\mathrm{D}_{1}$ and $\mathrm{D}_{2}$ proteins associated to photosystem II (Vivancos et al. 2011). The decrease in $\mathrm{PI}_{\text {Total }}$ indicates a lower provision of ATP and NADPH for the Calvin cycle (Gama et al. 2013) that coincides with the lowest efficiency in carboxylation calculated from the gas exchange variables.

The obtained results differ from the ones observed in Phaseolus vulgaris, in which glyphosate produced an inhibition of photosynthesis because of the stomatal closure whereas the photochemical stage was not altered 


\section{Meloni et al.}

(Olesen and Cedergreen 2010). These authors questioned the use of fluorescence variables as markers of stress by herbicides and suggested the use of gas exchange variables.

Shikimate concentration on leaves was very sensitive to glyphosate. In plants treated with both
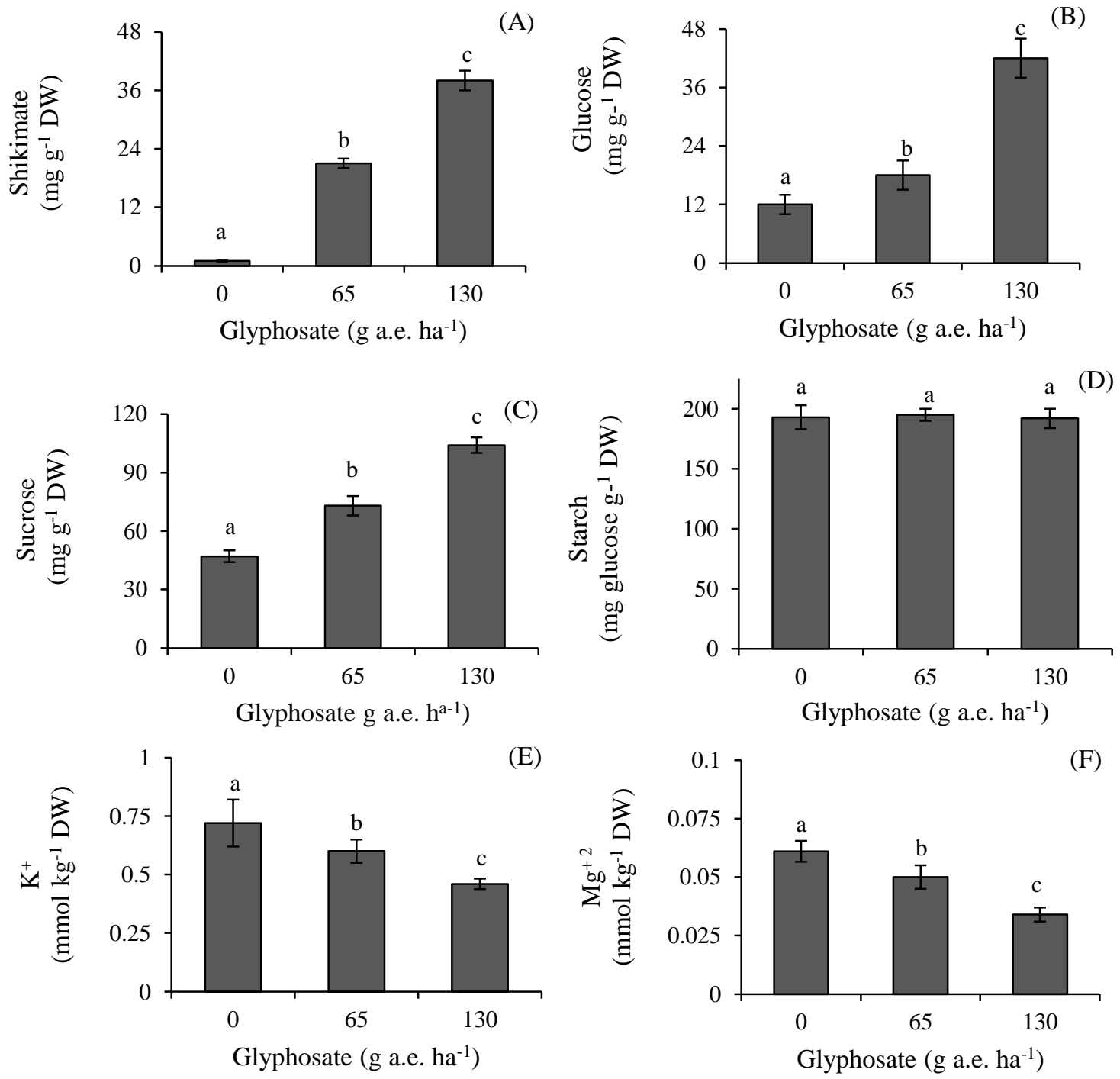

Figure 2. Shikimate (A), glucose (B), sucrose (C), starch (D), potassium (E), and magnesium concentrations (F) in E. camaldulensis plants submitted to 0,65 and $130 \mathrm{~g}$ a.e $\mathrm{ha}^{-1}$ glyphosate. Vertical bars represent the mean standard deviation. Different letters denote significant differences at level $\mathrm{P}<0.05$ according to Fisher's test.

Glyphosate produced a sharp increase in shikimate foliar concentration because of the inhibition of the EPSPS enzyme, representing a measurement of the susceptibility of one species to glyphosate. Thus, a species with low levels of shikimate might tolerate a higher dose of glyphosate (Palma et al. 2019). The high concentration of shikimate indicated the great susceptibility of E. camaldulensis to glyphosate, accompanied by an increase in the glucose and sucrose concentrations in leaves. Because glyphosate inhibited mainly the growing of tissues in active growing, it might produce a decrease in the demand of photoassimilates and thus an accumulation of carbohydrates in leaves. Yanniccari et al. (2012) suggested that the stomatal closure and the inhibition in $\mathrm{CO}_{2}$ fixation observed after the application of glyphosate might be due to the accumulation of the final products of photosynthesis. 
Glyphosate affected the mineral composition of leaves. In plants treated with both 65 and $130 \mathrm{~g}$ a.e. $\mathrm{ha}^{-1}$ glyphosate, $\mathrm{K}^{+}$concentration was reduced in 17 and $37 \%$ with respect to the control, respectively (Figure 2E). A similar trend was observed in $\mathrm{Mg}^{2+}$ concentration (Figure 2F). The effect of glyphosate on mineral nutrition has not been deeply studied, and there are contradictory results (Gomes et al. 2014). Glyphosate did not produce any changes in the mineral composition of glyphosate-resistant soybean cultivars (Zobiole et al. 2011). However, in glyphosate- sensitive soybean cultivars the absorption of macronutrients decreased, producing mineral deficiencies (Cakmak et al. 2009). Zobiole et al. (2012) also reported a significant decrease in the concentrations of microand macronutrients in soybean leaves treated with glyphosate. These plants had lower absorption and translocation of $\mathrm{K}^{+}$and $\mathrm{Mg}^{2+}$. The mineral
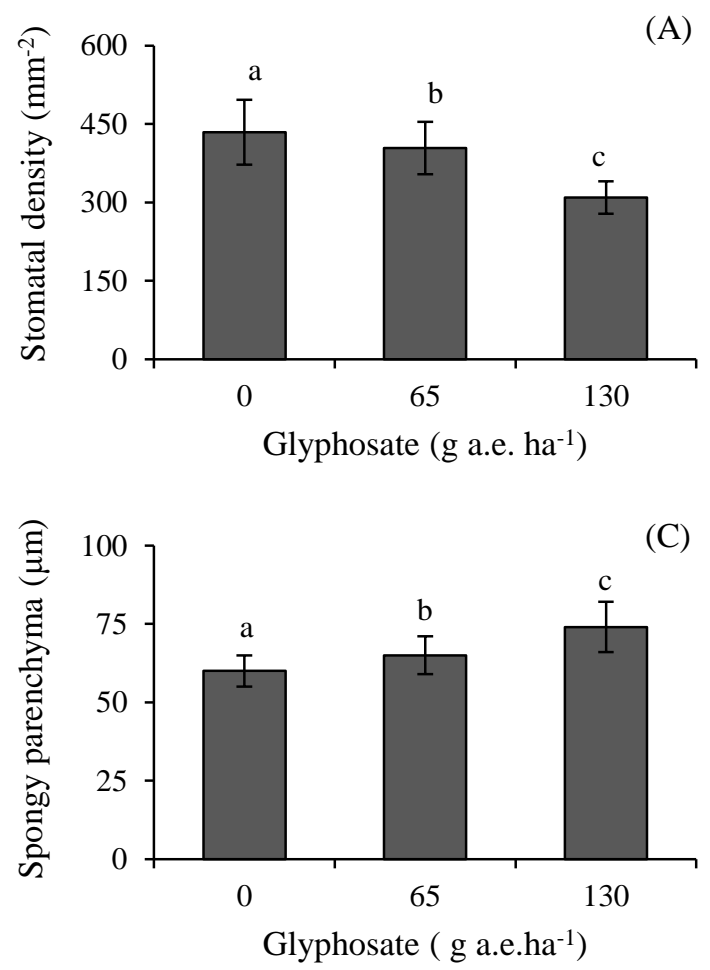

deficiencies produced by glyphosate have also been related with the inhibition in root growing (Zobiole et al. 2012). The decrease in $\mathrm{Mg}^{2+}$ and $\mathrm{K}^{+}$ concentrations might also be related with the reduction in chlorophyll concentrations and in the stomatal conductance observed in these trials. In effect, $\mathrm{Mg}^{2+}$ participates in the synthesis of the porphyrin ring of chlorophylls whereas $\mathrm{K}^{+}$regulates the stomatal openings and closures (Gomes et al. 2014).

The exposition to glyphosate produced a decrease in stomatal density, as the dose increased (Figure 3A), which agrees with observations presented by Lima et al. (2017) in plants of Bahuinia variegata using diuron.
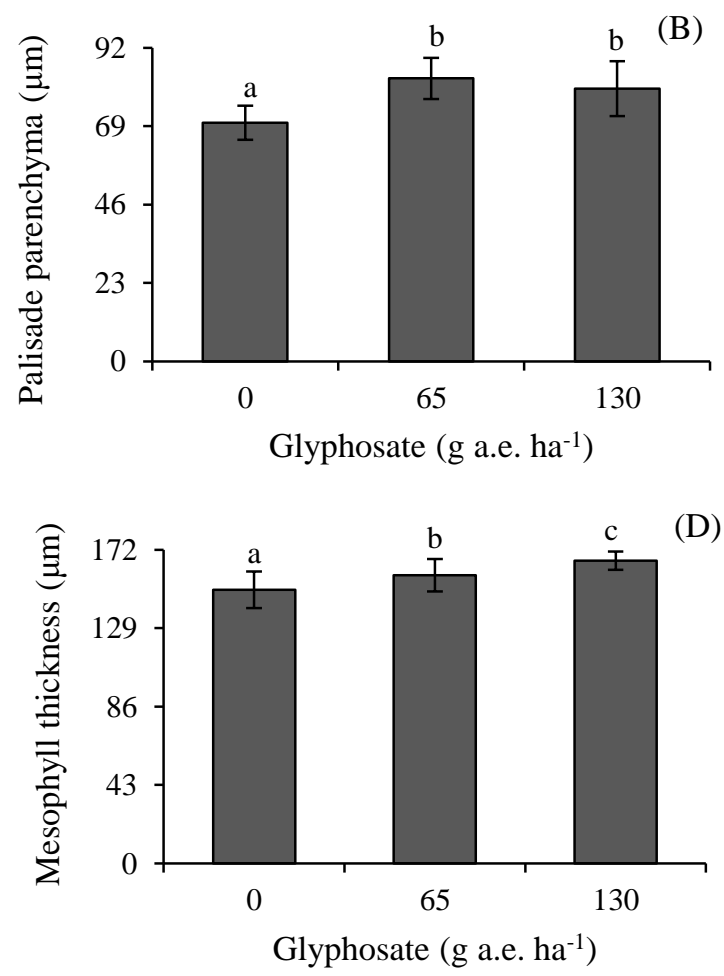

Figure 3. Stomatal density (A), Palisade parenchyma (B), spongy parenchyma (C) and mesophyll thickness (D) in E. camaldulensis plants submitted to 0,65 and $130 \mathrm{~g}^{2}$.e ha ${ }^{-1}$ glyphosate. Vertical bars represent the mean standard deviation. Different letters denote significant differences at level $\mathrm{P}<0.05$ according to Fisher's test.

The thickness of palisade parenchyma, spongy parenchyma and mesophyll, increased significantly as the dose of glyphosate increased (Figures 3B, C and D), in agreement with what was indicated by Tuffi Santos et al. (2008), because of the plasmolysis of some tissues and the hyperplasia manifested essentially in the parenchyma. According to Tuffi Santos et al. (2009), the anatomical responses to the simulation of glyphosate drifting in the foliar anatomy are associated with the response of the plant as selfprotection.

The stomatal inhibition of photosynthesis could have been caused by not only stomatal closure but also by the manifested decrease of stomatal density. The increase of soluble sugars is in accordance with the significant increase of the spongy parenchyma thickness. 


\section{Conclusions}

Glyphosate alters the physiology of $E$. camaldulensis, inhibiting photosynthesis, changing the metabolism of carbohydrates and the ionic homeostasis. Tissue disorganization, heavily marked at the level of mesophyll, indicates definite alterations.

\section{Acknowledgements}

The authors would like to gratefully acknowledge the financial support received from Consejo de Investigaciones Científicas y Tecnológicas, Universidad Nacional de Santiago del Estero (CICyT-UNSE), Argentina.

\section{References}

Al-Kahayri JM (2002) Growth, proline accumulation, and ion content in sodium chloridestressed callus of date palm. In Vitro Cellular and Development Biology 38: 79-82. doi: 10.1079/IVP2001258

Amin SA, Yon BA, Taylor JC, Johnson RK (2016) Changes in photosynthetic pigments and chlorophyll-a fluorescence attributes of sweetforage and grain sorghum cultivars under salt stress. Journal of Biological Physics 42: 601-620. doi: 10.1007/s10867-016-9428-1

Badr A, Brüggemann W (2020) Comparative analysis of drought stress response of maize genotypes using chlorophyll fluorescence measurements and leaf relative water content. Photosynthetica 58: 638-645. doi: $10.32615 /$ ps.2020.014

Batista PF, Costa AC, Megguer CA, Lima JS, Silva FB, Guimarães DS, Almeida GM, Nascimento KJT (2018) Pouteria torta: a native species of the brazilian Cerrado as a bioindicator of glyphosate action. Brazilian Journal of Biology 78(2): 296-305. doi: 10.1590/1519-6984.07416

Cakmak I, Yazici A, Tutus Y, Ozturk L. (2009) Glyphosate reduced seed and leaf concentrations of calcium, manganese, magnesium, and iron in nonglyphosate resistant soybean. European Journal of Agronomy 31(3): 114-119. doi: 10.1016/j.eja.2009.07.001

Cerveira Junior WR, Santos da Costa YK, Carbonari CA, Duke SO, Aguiar Alves PLC, Carvalho LB (2020) Growth, morphological, metabolic and photosynthetic responses of clones of eucalyptus to glyphosate, Forest Ecology and Management 470: 1-14. doi: 10.1016/j.foreco.2020.118218
Cruz CES, de Freitas-Silva L, Ribeiro C, Silva LC (2021) Physiological and morphoanatomical effects of glyphosate in Eugenia uniflora, a Brazilian plant species native to the Atlantic Forest biome. Environmental Science Pollution Resrearch, 28(17): 21334-21346. doi.org/10.1007/s11356-020-12003-4

De Carvalho LB, Stephen OD, Alves CA (2018) Physiological responses of Eucalyptus $\times$ urograndis to glyphosate are dependent on the genotype. Scientia Forestalis 46(118): 177-187

De María N, Becerril JM, García-Plazaola JI, Hernandez A, De Felipe MR, Fernandez-Pascual M (2006) New insights on glyphosate mode of action in nodular metabolism: Role of shikimate accumulation. Journal of Agricultural and Food Chemistry 54(7): 2621-2628. doi: 10.1021/jf058166c

Dizeo C (2000) Modificación de la técnica de inclusión en parafina de Johansen. Dominguezia 16(1): 55-58

Freitas-Silva L, Araújo TO, Nunes-Nesi A, Ribeiro C, Costa AC, Silva LC (2020) Evaluation of morphological and metabolic responses to glyphosate exposure in two neotropical plant species, Ecological Indicator, 113: 1-11. doi.org/10.1016/j.ecolind.2020.106246. 2020

Gama VN, Cunha JT, Lima IL, Bacarin MA, Silva DM (2013) Photosynthetic characteristics and quality of five passion fruit varieties under field conditions. Acta Physiologiae Plantarum 35: 941948. doi: 10.1007/s11738-012-1137-1

Gomes MP, Smedbol E, Chalifour A, HénaultEthier L, Labrecque M, Lepage LG, Lucotte M, Juneau P (2014) Alteration of plant physiology by glyphosate and its by-product aminomethylphosphonic acid: an overview. Journal of Experimental Botany 65: 4691-4703. doi: https://doi.org/10.1093/jxb/eru269

Gomes MP, Le Manac'h SG, Hénault-Ethier L, Labrecque M, Lucotte M, Juneau P (2017) Glyphosate-dependent inhibition of photosynthesis in willow. Frontiers In Plant Science 8: 1-13. doi: 10.3389/fpls.2017.00207

Gomes MP, Bicalho EM, Cruz FVS, Souza AM, Silva BMR, Gonçalves CA, Santos TRS, Garcia QS (2019) Does integrative effects of glyphosate, gibberellin and hydrogen peroxide ameliorate the deleterious effects of the herbicide on sorghum seed through its germination?, Chemosphere 233: 905912. doi: 10.1016/j.chemosphere.2019.06.032

Huang J, Silva EN, Shen Z, Jiang B, Lu H (2012) Effects of glyphosate on photosynthesis, chlorophyll fluorescence and physicochemical properties of cogongrass (Imperata cylindrical L.). 
Plant Omics 5(2): 177-183. doi: 10.3316/informit. 188983836705674

Khan S, Zhou JL, Ren L, Mojiri A (2020) Effects of glyphosate on germination, photosynthesis and chloroplast morphology in tomato, Chemosphere 258: 327-335. doi: 10.1016/j.chemosphere.2020.127350

Lichtenthaler HK, Welburn AR (1983) Determination of total carotenoids and chlorophylls $\mathrm{a}$ and $\mathrm{b}$ of leaf extracts in different solvents. Biochemical Society Transactions 11: 591-592. doi: 10.1042/bst0110591

Lima DA, Müller C, Costa AC, Batista PF, Dalvi VC, Domingos M (2017) Morphoanatomical and physiological changes in Bauhinia variegata L. as indicators of herbicide diuron action. Ecotoxicology and Environmental Safety 141: 242-25. doi.org/10.1016/j.ecoenv.2017.03.038

Meloni DA, Silva DM, Ledesma R, Bolzón G (2017). Nutrición mineral y fotosíntesis en plántulas de algarrobo blanco, Prosopis alba (Fabaceae) bajo estrés salino. UNED Research Journal 9: 297-304. doi: 10.22458/urj.v9i2.1903

Minogue PJ, Osieka A (2015) Selective herbicides for cultivation of Eucalyptus urograndis clones. International Journal of Forestry Research 5: 1-12. doi:10.1155/2015/341314

Olesen CF, Cedergreen N (2010) Glyphosate uncouples gas exchange and chlorophyll fluorescence. Pest Management Science 66: 536542. doi:10.1002/ps.1904

Orcaray LO, Zulet A, Zabalza A, Royuela M (2012) Impairment of carbon metabolism induced by the herbicide glyphosate. Journal of Plant Physiology 169(1): 27-33. doi: 10.1016/j.jplph.2011.08.009

Palma BC, Torra J, Garcia MJ, Bracamonte E, Rojano-Delgado AM, Alcántara-de la Cruz R, De Prado R (2019) Reduced absorption and impaired translocation endows glyphosate resistance in Amaranthus palmeri harvested in glyphosateresistant soybean from Argentina. Journal of Agricultural and Food Chemistry 67: 1052-1060. doi: 10.1021/acs.jafc.8b06105

Portela FCS, Macieira BPB, Zanetti LV, Gama VN, Silva DM, Milanez CRD, Cuzzuol GRF (2019) How does Cariniana estrellensis respond to different irradiance levels? Journal of Forestry Research 30: 31-34. doi: 10.1007/s11676-0170578-1

Radwan DEM, Fayez KA (2016) Photosynthesis, antioxidant status and gas-exchange are altered by glyphosate application in peanut leaves.
Photosynthetica 54: 307-316. doi: 10.1007/s11099016-0075-3

Santos JA, Santos TLD, Ferreira FA, Ferreira LR, Felix RC, Amara, GC, Cruz LR (2015) Glyphosate drift in Eucalyptus plants. Planta Daninha 33: 615621. Doi:1590/S0100-83582015000300024

Serra A, Nuttens A, Larvor V, Renault D, Couée I, Sulmon C, Gouesbet G (2013) Low environmentally relevant levels of bioactive xenobiotics and associated degradation products cause cryptic perturbations of metabolism and molecular stress responses in Arabidopsis thaliana. Journal of Experimental Botany 64(10): 27532766. doi: 10.1093/jxb/ert119

Siehl D (1997). Inhibitors of EPSPS synthase, glutamine synthetase and histidine synthesis. In: Roe R, Burton J, Kuhr R, eds. Herbicide activity: toxicology, biochemistry and molecular biology. Amsterdam: IOS Press, 37-67

Singh B, Shaner D (1998) Rapid determination of glyphosate injury to plants and identification of glyphosate-resistant plants. Weed Technology 12(3): 527-530. doi: 10.1017/S0890037X00044250

Sousa CP, Farías ME, Shock AA, Bacarin MA (2014) Photosynthesis of soybean under the action of a photosystem II-inhibiting herbicide. Acta Physiologiae Plantarum 36: 3051-3062. doi:10.1007/s11738-014-1675-9

Tuffi Santos LD, Sant'Anna-Santos BF, Meira RMSA, Tiburcio RAS, Ferreira FA, Melo CAD, Silva EFS (2008). Danos visuais e anatômicos causados pelo glyphosate em folhas de Eucalyptus grandis. Planta Daninha, 26(1): 916. doi:10.1590/S0100-83582008000100002

Tuffi Santos LD, Sant'Anna-Santos BF, Meira RMSA, Ferreira FA Tiburcio RAS; Machado AFL (2009) Leaf anatomy and morphometry in three eucalypt clones treated with glyphosate Brazilian Journal of Biology 69(1): 129-136. doi:10.1590/S1519-69842009000100016

Van der Westhuizen MM, Oosterhuis DM, Berner JM, Boogaers N (2020) Chlorophyll a fluorescence as an indicator of heat stress in cotton (Gossypium hirsutum L.). South African Journal of Plant and Soil, $\quad 37(2)$ : 116-119. doi:10.1080/02571862.2019.1665721

Vivancos PD, Driscoll SP, Bulman CA, Ying L, Emami K, Treumann A, Mauve C, Noctor G, Foyer CH (2011) Perturbations of amino acid metabolism associated with glyphosate-dependent inhibition of shikimic acid metabolism affect cellular redox homeostasis and alter the abundance of proteins involved in photosynthesis and photorespiration. Plant Physiology 157(1): 256-268. doi:10.1104\%2Fpp.111.181024 


\section{Meloni et al.}

Yanniccari M, Istilart C, Giménez DO, Acciaresi H, Castro AM (2012) Glyphosate effects on the growth and free sugar accumulation of two Lolium perenne biotypes with different herbicide sensitivity. Planta Daninha 30: 155-164. doi: 10.1590/S0100-83582012000100018

Zobiole LHS, Kremer RJ, Oliveira Jr. RS, Constantin J, Oliveira RS (2011). Glyphosate affects chlorophyll, nodulation and nutrient accumulation of "second generation" glyphosateresistant soybean (Glycine $\max$ L.). Pesticide Biochemistry and Physiology 99(1): 53-60. doi: 10.1016/j.pestbp.2010.10.005

Zobiole LHS, Kremer RJ, de Oliveira Jr. RS, Constantin J (2012) Glyphosate effects on photosynthesis, nutrient accumulation, and nodulation in glyphosate-resistant soybean. Journal of Plant Nutrition and Soil Science 175(2): 319330. doi: 10.1002/jpln.201000434 